\title{
RELIGIOUS AND GENDER ISSUES IN THE TRADITION OF BASURUNG AND THE POLYGAMY OF BANJAR TUAN GURU IN SOUTH KALIMANTAN
}

\author{
Wardatun Nadhiroh \\ UIN Antasari Banjarmasin \\ Email: wnadhiroh@iain-antasari.ac.id
}

\begin{abstract}
Banjar is among the largest ethnic groups in Kalimantan Island, concentrated in South Kalimantan and a small part of other Kalimantan. As an adherent of Islam, Banjar ethnic group is very religious. Tuan guru, a designation for respected ulama, play as a role model in everyday life. The have a gathering for studies (pengajian) that are always attended by a large number of followers (jamaiah). People want to be close to this elites, making them as apart of their family. For the sake of this effort, the female jama'ah often 'basurung' of offering to be married by the tuan guru. As a parent they also offer their daughter to marry him. Banjar women will feel honored when they marry a tuan guru, although it turns out to become "an informal wife." Her family will also be very proud to be able to be bond to a respected tuan guru. As a result, it is no wonder that there are many tuan guru in South Kalimantan who have more than one wife. This paper discusses the culture of basurung initiated by the women of Banjar ethnic group using standpoint of feminism analysis. The work attempts to see the women's points of view, especially in relation to the tuan guru's polygamy culture that occurs within Banjar ethnic group.
\end{abstract}

Keywords: Banjarese, polygamy, tuan guru, women, basurung, tradition.

\section{INTRODUCTION}

One wife is fair

Two wives are learning

Three wives are insolent

Four wives are Banjarese

The above quote is famous among Banjarese. Non-Banjarese may be surprised when they first hear the anecdote. They may not believe that Banjar women tend to allow the practice of polygamy in their marriage. In fact, it is true that many Banjar men are in a polygamous marriage - married to more than one woman. An interesting fact is that, in the structure of Banjar society, the practice of polygamy is done mostly by the charismatic ulama or somenone 
who is widely known as tuan guru ${ }^{1}$ (Hapip, 1977). Most women actually never want to be involved in a polygamous marriage due to many reasons. Yet, Banjar women consider the polygamy merriage by tuan guru as an important issue. For many cases of polygamy involving tuan guru, there is a unique phenomenon in which some women offer themselves to be married to a tuan guru. They sometimes directly speak to a tuan guru or ask their family members to help them. They are very aware that they will become an informal wife if the tuan guru accepts the proposal. This is what is called the tradition basurung ${ }^{2}$ in Banjar community.

It is intersting to explore the opinion of the wifes of Tuan Guru Banjar on polygamy. Apparently, the issue of polygamy for them is not a frightening matter. They are proud of being the spouses of a tuan guru who is materially and spiritually well-established. This work discusses the Banjarese tradition in which the women consider as the victim in the polygamy practice, although somehow ithey nitiate consciously a polygamous marriage to a tuan guru. There are some questions that must be answered. First, why do the Banjar women initiate to be involved in a polygamous marriage with a tuan guru. Second, how they perceive the concept of polygamy itself. This work attempts to present the Banjar women's thought about polygamy. It is based on a qualitative study using the standpoint of feminism ${ }^{3}$ approach to prepare the view of Banjar women about the pros-cons of polygamy. It means that the issues will be based on the writer's viewpoints as a double-consciousness subject. On other words, women are the active parties who formulate and interpret the process of the social relationship in the daily life.

\section{THE DISCOURSE OF POLYGAMY IN ISLAM}

Islam covers the terminology of polygamy as taaddad al-zaujat or having several wives. The provision of polygamy is normatively regulated in Sura alNisa (verse3). The word "polygamy" is derived from Greek, "poly or polus"

${ }^{1}$ The meaning of Tuan Guru in this work is a charismatic and famous ulama whose knowledge of Islam is not debatable, with many followers and a routine agenda of teaching Islam.

${ }^{2}$ Basurung is a practice of banjar woman who consciously offer herself to be married by a tuan guru. Although she knows that the tuan guru has been married, it does not seem to be a problem for her.

${ }^{3}$ Standpoint of feminism argues that feminism in social science should be practiced from the standpoint of women or particular groups of women as some claim that they are better equipped to understand certain aspects of the world. A feminist or women's standpoint epistemologycally proposes to make women's experiences, instead of men's, as the point of departure. Standpoint of feminist theorists attempt to criticize dominant conventional epistemologies in the social and natural sciences, as well as defend the coherence of feminist knowledge as Invalid source specified. 
which means many and "gamein" which means marriage. Thus, polygamy is a marriage that involves many men or women (Dahlan, 1997, p. 107). In Kamus Besar Bahasa Indonesia (Indonesia, 2008, p. 799), polygamy is a marital system which one party marries some opposite parties at the same time. Based on the mentioned definitions, there are two meanings of polygamy, namely polyandry and polygyny. Polyandry is a marriage between a woman and some men. While polygyny is a marriage between a man and some women. In Indonesia, polygamy is practically limited to the concept of polygyny which a man might have more than a woman as his wifes in the same time. Indonesian matrimony institution only permits polygyny, not polyandry. The term taiaddad al-zaujat in Islam is identically related to the concept of polygyny. However, most Muslims have already addressed the term ta'addad al-zaujat as polygamy.

People in the Arabian countries in the era before Islam had practiced polygamy. People in European countries such as Russian, Yugoslavian, Czech, Germany, Belgian, Netherlands, Denmark, Sweden and British also recognizeed polygamy (Alhamdani, 1980, p. 80). Muslims argue that Islam does not start polygamy but controll the number of wifes and clearly specified the regulation. In the past, when the companions came to Prophet Muhammad and told him about their polygamous marriages, the Prophet asked to the companions to choose only four wifes and divorce the rest. Islam permits polygamy with four wifes by means of being able to be fair to the wives as managed in the Koran in Sura al-Nisa (verse 3). What means fair is certainly in sustenance, residence, clothing, and other material things, while the majority of scholars have different opinion of fairness in affection. So, when a man cannot fulfill the provision, he must do only monogamy. In terms of being fair to the wives, Allah has explained its difficulty as revealed in the Koran in Sura al-Nisa' (verse 129) (Azhar, 1996, pp. 76-77).

The Prophet experienced the difficulties to be fair in his marriage with 11 wives. Because of that, when some Quraisy leaders met him to ask permission for Ali, Fatimah's husband, to marry their daughters, the Prophet declined it (HR. Bukhari and Muslim). Ali married again just after the Prophet and Fatimah passed away. The Prophetic History has shown that the Prophet married monogamously to Khadijah for 24 years, longer than his polygamous marriage which is about 10 years in the late of his life. Unfortunately, the Prophet's polygamy practice is considered as a model of attitude, even called as the Prophetic tradition, while his monogamous life is forgotten. In fact, the Prophet never encouraged polygamy and he even rejected it in relation to his daughter's marriage. 
Generally, there are three main thoughts about polygamy in Islam. The first argues that one who practices polygamy follows the prophetic tradition and automatically gets God's merit. For this argument, polygamy is recommended only to those (men) who are capable to practice it. Polygamy becomes an instrument to measure men's faith (Setiati, 2007, p. 23). The second explains that polygamy is not encouraged but is just allowed in certain condition. For example, one may practice polygamy to avoid an adultery, to help penniless widow, or when a hasben faces the fact that his wife is sick and cannot fulfill the dutties as a wife. The last believes that polygamy must not be done in this era. According to the lat argument, the Prophet practiced the polygamy only for certain reasons. As known in the prophetic history, many wars happened in the age which resulted many companions killed leaving their wives and children. All of them needed protection which may be obtained from polygamous marriage. This lates argument also perceives that the meaning of Sura al-Nisa (v.3) is to limit the number of wife and to remove the practice of polygamy/ polygyny gradually (Chodjim, 2007, p. 55). The disability of men, except Prophet Muhammad, to be fair to their wifes is being the concerned of the argument.

Nurmila divides women's response to polygamy into three groups. The first group accommodates the practice of polygamy, the second one positions into semi-accommodation, and the last refuses the practice of polygamy (Nurmila, 2009 , pp. 80-92). Nurmila's classification is based on women's understanding on Islamic Law, Qur'an and Hadith. Nurmila shows that women who literally understand the texts tend to accept the practice of polygamy. While the semi-textual is resistant to the concept of polygamy. However, women who contextually understand the text tend to decline the idea of polygamy clearly. According to Abd. Rahman Ghazali, Islam principally views the idea of polygamy as riskier than monogamy (Ghazali, 2003, p. 131). As human nature, everybody has negative sides such as jealousy, envy, and complaints. The negative sides will easily appear in the polygamy marriage. Then, some conflicts may arise in the household like quarrel between husband and wife, between their children of each wife, etc. So, the fundamental of marriage in Islam is monogamous because it will easily neutralize jealousy, envy, and complaints.

Apart from the pros-cons of polygamy, it is a fact that the practice has already been one done until today. Undoubtedly, many practices of it have already found within Muslim community. The implementation often tends to fulfill selfish goal only, either biological needs or theological justification. Whereas the polygamous marriage is required to meet two basic related-needs, namely 
biological need in one side and theological demand as explained in Sura al-Nisa (v.1-5). Many practices of polygamy use religious provision as a justification while the actual orientation is pure biological need. The practitioners argue that polygamy is an ideal solution to avoid adultery, disloyalty, and sirri ${ }^{4}$ marriage. In fact, many polygamous marriage occurr in the form of the sirri marriage.

\section{BANJARESE IN SOCIAL AND CULTURAL CONTEXT}

Banjar ethnic group inhibitates Kalimantan Island, especially in Southern region as their origin. The community of Banjar ethnic group is more known as Banjarese. Ideham (as quoted by Daud, 1997) explains that Banjarese is an ethnic group occupying the coast of South Kalimantan, East Kalimantan, and Center Kalimantan in the beginning. In the colonial era, the local people in the island were classified into two biggest groups, namely Muslims and non-Muslims. Muslim community is identified as Malay and non-Muslim is affiliated to Dayak tribe. Because Banjar ethnic group is one of the Malay family, it is included into Muslim group. The spread of Islam in South Kalimantan has increased very rapidly. The Statistic data of South Kalimantan's population in 2016 presents that 4.055 .479 or $97 \%$ of all its inhabitants are Muslim. Alfani Daud mentions that all Banjarese are Muslims incuding those converted to Islam from Dayak tribe who are considered to be Banjarese (Daud, 1997, p. 5). Judith Nagata, as quoted in the Ahmad Gaus AF's book, states that Banjar is an ethnic identity that overlaps with religious identity, "religion is ethnic, ethnic is religion" (AF, 2009, pp. xi-xxii).

The Directorate of History and Traditional Values of South Kalimantan mentions that the Banjar ethnic group is an ethnic that instills Islamic contents in their behavior and in socio-cultural matters (The Directorat of History and Tradisional Values, 1985, p. 14). The teachings of Islam are carried out dutifully by Banjarese so that it is a fact that there are many mosques and langgar/surau (small mosque) found in South Kalimantan. Religious activities such as religious teachings and lectures are also widely implemented, especially in the month of Ramadhan. Therefore, in Banjar society, the term 'Islam Banjar' which is known as the Islamic religion of Banjarese does not stop at the institution of belief only, but also has been melted in the daily life order and in the customs, held and implemented by the local community. Similarly, studying and learning the Qur'ran are activities carried out by children in the mosque with a teacher or tutor that have never been neglected.

${ }^{4}$ Informal marriage withouth resgistered to the institutions in change of merital administration. 
Implementation of the pillars of Islam such as giving charity, and performing hajj or umrah are also growing very promising in South Kalimantan. The number of people doing the hajj and umrah are increasing every year.

Although it is known that the Banjarese are fanatical Muslims, they also have a mystical belief of local culture as bagampiran and wearing amulets (Nor Ipansyah, 2010, pp. 85-87). The same thing has also been emphasized Alfani Daud that Banjarese believes to be devout Muslims. In addition to the obedience to the teachings of Islam, there are religious beliefs and some behavior that are not in reference to Islam but of local culture (Daud, 1997, pp. 581-592). This behavior is exemplified as the belief of 'the divine', 'magical companions', the ceremonial birth, belief in luck thing, funerals, also about 'the good' and 'bad day'. According to Alfani, it is the 'framing' of Islam by local culture (Daud, 1997, p. 541). The structure of Banjar community, according to Syaharuddin, is divided into four groups, namely government officials, traders, teachers (alim ulama) and farmers. They are all bound by Islam as its social identity (Syaharuddin, 2009, p. 34). While the life philosophy embraced by Banjar community has focused to obtain the quality of welfare. From the interpretation of Alfani as cited by Hadi, temporarily the life purpose of the Banjarese is twofold; the welfare in the "near future" and the welfare in the "distant future" (Hadi, April-Juni 2015, p. 214). The well-being of the near future means the prosperous life of the world, while the well-being of the distant future is the prosperous life in the Hereafter. Of the two kinds of objectives, the main priority is the orientation of the Hereafter.

With such a culture, the group of ulama ultimately plays an important role in the spread and the teaching of Islam in the land of Banjar. The ulama who are often referred to tuan guru is a role model in everyday life. What they recommend will undoubtedly be done by Banjarese. The people who become the central figure in the Banjar community's religious life are respected because of the their knowledge, the moral praise, piety, and concrete roles they have done in nurturing the community. Their position is very high in the structure of Banjar community. Their arrival has been welcomed and respected. The tuan guru has always been a place to return all the problems faced by the society, whether it concerns religious issues or other problems that occur in everyday life. The most heavily consulted cases are about the distribution of inheritance, marriage, debts, and worship issues. Others are issues related to family life (marital relationships, juvenile delinquency, parent-child conflicts, conflicts of law-in-laws, including dating matters), daily living matters such as employment (no permanent employment, readiness to accept job offers, an imbalance between income and expenditure), and the disharmony of 
neighboring life. In fact, there are also people who consult for the problem of spiritual treatment or healing for psychiatric disorder (Makmur, 2012, p. 181). In addition, officials who want to nominate for the election, frequently ask for 'blessing' to tuan guru. With such a phenomenon, it seems that Banjarese have a 'dependence' on the figure of tuan guru. In fact, not only during their lifetime, these tuan guru are respected, even after their death. Their graves are still crowded because they are believed to have karamah. ${ }^{5}$ On one side, the awareness of the need to always have the advice and spiritual splashes from the tuan guru as the leader of the ummah is a good thing, but on the other side, when consciousness becomes a dependence, it will lead to an indiscriminate worship, affect negatively to the face of Islam Banjar.

\section{THE POLYGAMY BY TUAN GURU IN BANJAR}

Idwar Saleh argues that the Banjarese, in accordance with the teachings of Islam, are allowed to marry up to four times on a condition that the men must be able to be fair among the wifes (Saleh, 1991: 92). One of the fair forms according to Banjar custom is that a man deserves to get married again after he is able to give wealth to his former wife. Therefore, men who do polygamy are usually those who have sufficient economic capabilities as it is not surprising that commonly the polygamous perpetrators are the baduit (rich) people. In addition to the baduit people, in the Banjar community, polygamous perpetrators are also known as alim ulama, especially those who receive the title "tuan guru". It is said that the ketuanguruan of a tuan guru has not been tested if his wife is only one. In the recorded history of Banjarese ulama, it can be traced to such figures as Sheikh Arsyad al-Banjari during his life to have the wife of 11 women, even though they were not married at one time. There are still many ulama of Banjar whose life are recorded to practice polygamy.

In practice, there is a fundamental difference between the polygamy practices committed by the rich in Banjar and by a tuan guru. The baduit groups mostly choose their polygamy pairs by looking at physical beauty as their primary consideration, so they often go straight to choose the woman. While in the case of the polygamy of tuan guru, the upcoming wife is not sought but comes to approach the man, whether it is from the woman's request personally or from the woman's relative who willingly gives her to tuan guru. Whilr in many cases of polygamy committed by the baduit, the previous wife does not know that she is in a polygamous marriage because the next marriage is done informally (sirri) and mostly withouth the first wife permission. The issue of permission of this wife has been alluded to by Idwar Saleh in his book (Saleh,

${ }^{5}$ It means blessing. 
1991, pp. 92-93) mentioning that the polygamous Banjar Baduit men do not ask permission from his first wife. Few men are willing to marry another woman by seeking permission from their earlier wifes. This can be seen from the notes at the High Religious Court of Banjarmasin which in 2011 recorded 10 cases of polygamy without previous wife's permission imposed in the court. Most polygamy is done secretly. And when the first wife knows the caase, she would sue for divorce to her husband. This is reflected in several notes by the High Religious Court of Banjarmasin during 2011, which record 468 divorce cases categorized as divorce due to third party interference. This third-party interference category ranks fourth highest in cases terminated by the Religious High Court of Banjarmasin.

In the practice of polygamy by tuan guru in Banjar, the demands of polygamy come from other parties, not by the men. For example, the polygamy of a tuan guru in Hulu Sungai Tengah (HST) district shows that his second wife was married because of the urging of the wife's parents' request to the Tuan Guru marry their daughter. Although the second wife initially rejected the matchmaking of the parents, but in the end, she also accepted it. The two tuan guru's wifes live in harmony and close together as neighbour. ${ }^{6}$ Such a phenomenon is inherently common in Banjar society, where the woman, whether it comes from the request of the woman or on the consideration of her parents, begs to be married by a tuan guru and knows that the tuan guru has been married. The problem is only whether the request is accepted or rejected. This was once disclosed by tuan guru SY when he gave lecture in a langgar in HST District, that many offers to do polygamy come to him from various circles, but he still adheres to the principle of monogamous marriage alone, once forever. Although many offers come from women who are willing to be polygamous spouse, the tuan guru's decision to do polygamy himself is based on certain reasons that have been considered and certainly discussed with his previous wife. The first wife usually knows and gives her husband permission to do polygamy. Frequently, the first wife helps to pick the polygamous spouse for her husband. This particular polygamous marriage is usually done officially. In the polygamous marriage is done by tuan guru, the previous wife figure always reflects the sincere acceptance of her husband's polygamy behavior and the presence of other women who will also take the attention and affection of her husband.

From some cases of polygamy by those tuan guru in Banjar, the specific reasons underlying the actions of these polygamy differ from one another. Some do polygamy for the reasons of getting offspring. A very human reason given

${ }^{6}$ An interview with FS who is a relative of the second wife of the tuan guru in HST District from his father's lineage. 
that a tuan guru would want his offspring to continue the da'wah he has done. In such cases, the previous wife often helps to pick out her honey mate. ${ }^{7}$ Even such reasons are often explained to the audience when explaining about polygamy, the more wives, the more and more generations of descendants, the more successors of da'wah later. In the case of the other tuan guru's polygamy, it is closely related to the request of the woman's parent to have her daughter to be married by the tuan guru. There are some underlying reasons of parents in Banjar who ask the tuan guru to marry their daughter. In the mind of the parents, even though he was married, the tuan guru as a religious person must be able to act justly among his wifes and be a good priest for their daughters and be able to guide them to the path of goodness. The parents will not feel worried for offering their daughter to be married by the tuan guru. The same thing was expressed by the later wife. In addition, as mentioned eralier, the tuan guru becomes the center of all problem solving, whether it is related to material or spiritual matters, or in terms of 'self-medication'. Men and women come to the tuan guru to bring all kinds of problems and ask for advice and prayers. The intensity of 'meeting' is often felt to invite slander, especially if a woman repeatedly come to see the tuan guru. From there, it can appear the initiative for polygamous marriage.

The polygamy behavior of the tuan guru in the Banjar community often comes without any criticism from the community. In the society, it is believed that it is not good to take care of other people's business. The people believe that with the capacity as tuan guru, one will be able to fulfill the requirements to practice polygamous marriage; that is to be able to be fair and support their wifes well. As a public figure, surely all the acts of speeches and behavior of a tuan guru become examples of life in the society, including his polygamy practice. Therefore, the people's belief is a very strong factor in the behavior of polygamy to grow among the Banjarese. The community will imitate the tuan guru's actions.

\section{THE CULTURE OF BASURUNG}

The discussion of this section is centered on the facts behind the phenomenon of the tuan guru's polygamy practice in Banjar that involves the women as active actors who willingly want the polygamy. It is called basurung culture, meaning the practice of a woman who consciously offers herself to be married by a tuan guru although she knows that the tuan guru has already has a wife. This basurung culture has actually become a common secret in the portrait

7 An interview with a female respondent who lives next to a tuan guru's home in Banjar, often attended the tuan guru's pengajian, and interacted very well with his first wife in the neighborhood. 
of the Banjar community. In this basurung culture, although it is said that the demand comes from the women, it is well known that in practice the cultural initiator can be divided into two, that demand may come from the women who are willing to do polygamy themselves and the request of the parents or the family of the women who intends to 'hand over' their daughter, sometimes even without their daughter's consent. Although it is said that the basurung culture of women in Banjar has become a public secret, it is in fact is only famous within the circle of people who feel having an emotional attachment to a tuan guru, either because they are the tuan guru's jama'ah pengajian or the community around the tuan guru's places of living who do interact in their daily lives, and not from the general public who are far from the socioreligious invironment.

For the members of the jama'ah, the phenomenon of "requesting" the tuan guru to marry their duthters is a common understanding. The underlying factor of the phenomenon is the magnitude of the tuan guru's charisma which becomes the magnet or the attraction for the women of the jama'ah. The understanding that the tuan guru is a figure who has a respectable position in the community, knowledgeable, and living well has been the reason for Banjar women to do the Basurung. A son of a pratitioner of basurung said that when his young mother once did basurung to a tuan guru in his village, it was because she was fascinated with the Tuan Guru's shade and wisdom. But she was rejected by the tuan guru due to different reason. ${ }^{8}$ Another female who becomes an active jama'ah of a tuan guru's pengajian mentioned: "who does not want to marry a tuan guru, he is already pious, rich, well-established materially, and in the hereafter, will be guaranteed by Allah."

As previously discussed, the Banjarese are welknown as people who have full of religious nuances in Saouth Kalimantan with tuan guru as the very important figure in the formation of the society. A tuan guru has a great power and influence to mobilize the people for many purposes, especially for religiously based activities. A tuan guru says and asks and no jama'ah or community will reject it. The views of a tuan guru in Banjar are powerful and able to influence or even shape new opinions in the society. Therefore, some officials ask for support of the tuan guru for their political supports. This all shows how high and honorable the position of a tuan guru in the sight of the Banjar community. In Banjar culture, a basurung woman does not necessarily

${ }^{8}$ MS is a male respondent who involves closely and 'follows' the daily life of a tuan guru in Hulu Sungai Utara District. In fact, sometimes he was asked to replace if the tuan guru was unable to fill the pengajian that most jamaah are women.

${ }^{9}$ SR is a female respondent who have been jama'ah actively and have followed many pengajian existing in Hulu Sungai Tengah District, sometimes even to the city of Banjarmasin and surrounding areas. 
have to be a never married woman. It is also found that widows still offer to become a next wife to a tuan guru. If the request of this basurung is accepted by a tuan guru, then not only the woman will become more honorable, but also her family will feel very proud of having a son-in-law or relative of an ulama in the community. Their image and social status will be increasing. Given the position of a tuan guru in Banjar that is very high in the view of the community, people do not criticize and talk about this kind of polygamy behavior in public. It is often regarded as a taboo thing to talk about it.

This phenomenon of Banjar women doing basurung does not mean the final conclusion that all Banjar women have a desire to do so. With the religious life being the identity that covers the daily life, it can be said that all the women in Banjar want men who are pious and understand in religion as a husband and leader in the household. But that does not mean the meaning of pious men and understand this religion is a person who is a tuan guru. It is also found that these Banjar women doing basurung are those who have an emotional attachment to the tuan guru, as they have been enchanted by the tuan guru's charm and charisma. It is also found that those who do basurung to a tuan guru are not from the ordinary strata, but women from the middle to upper economic levels. For these people, it is not about economical reasons behind the practice but more about religious inflences from a spiritually wellestablished person.

\section{BANJARESE WOMEN POSSITION IN POLYGAMY}

Polygamous marriage is a sensitive issue for gender activists. Basically this kind of marriage places women as the object and the man as the subject. Some cases shows that the life of polygamous women is more with sadness than happiness. Some types of violence may occur in several contexts including emotional, economics, physics and sexual (WCC, 2001: 5,8). This indicates that women who live in marriage with husbands who have more than one wife are particularly vulnerable to violence. In some cases of polygamy, there are a continuous violence. The first wife not only experiences the denial of marital commitment, but also has psychological, economic and sexual-physical pressure. As for the second wife, things are not much different (Mulia, 1999: 50-58). Psychologically, all wives will feel hurt when they see their husband in touch with other women. There are at least two factors that cause it. First, it is driven by their deep loving feelings to their husband. Generally the wife trusts and loves her husband wholeheartedly so that no more room in her heart love towards other men. The wife always hopes her husband to apply the same to her. Therefore, the wife cannot accept her husband to share his love 
to another woman. Second, the wife feels herself inferior as if her husband do polygamy. The inferior feeling is increasingly becoming a psychological problem, especially when it comes from the family pressure (Zaini, 1999: 133144).

Another psychological problem is in the form of internal conflicts within the family, whether between fellow wifes, between wifes and stepchildren or among children of different mothers. There is a sense of unhealthy competition between wifes. Certainly, it will cause serious social problems in the society. A person who is educated and appreciates what is required by Syara' will not have the initiative to do polygamy. Therefore, the more educated and civilized society the fewer polygamy practices are found (Syarqawi, 2003: 239-250). In a previous study conducted by Roibin (Roibin, 2007: 8-10), it was found that in the case of polygamy involving ulama, kiai, or tuan guru, there are two motivations underlying these polygamous peoples. First, normativetheological motivation which is based on the understanding that polygamy is a religious laws. The understanding is inspired by the calling of sacred texts literally without being matched by humanistic efforts and behavior. The attitudes and practices of polygamy for this community are regarded only as a value system and not a cognitive system that is always evolving to adjust the contents of local wisdom. As a result, the polygamy leaves many problems both within the internal family personally and the surrounding community. Some of the reasons justified for polygamy for this category include that it is due to religious appeals, the belief that women should be led by men, the belief that women are part of men and the belief that the women are weak. All of these theological normative reasons always refer to religious texts. Meanwhile, the approach of understanding and interpretation of the Sacred Texts is textual which emphasizes toward understanding the word and the language. While the dimension of the historicity of the text, as if by this community is ignored. The second motivation that most underlies to do polygamy can be called as normative-humanistic motivation. This behavior is based on an understanding to bring the spirit of the calling of the Sacred Texts (value system) and the meaning of the textual contextuality of the universality of the text into the life praxis (cognition system). Some reasons behind polygamy in this form include placing the dignity of women, raising and changing the social status of women and also of course their family, having intimate friends to develop Islam, multiplying qualified Muslim cadres whose intelligence, good moral, and charitable and developing a culture of help between strong and weak because of religious advice.

Although the two mentioned motivations seem to be contradictory because 
they are brought up from different perspectives, they both seem to both place women in an inferior, weak, and 'assisted' position. The supremacy of men in the two discourses above, especially with their capacity as a religious elite, is highlighted strongly, as if only with their help, the dignity and degree of women can be accommodated. Mukti Ali, as quoted by Aulawi, mentions that it is like an airplane that already has a complete navigation equipment with enough crew. The aircraft is not allowed to fly if it is not equipped with an 'emergency door'. So beside the regular door, the plane should have emergency exits. However, for people who want to get on board a plane must take a regular door, not through the emergency exit. Only in a very urgent need, a new emergency door is allowed to be operated. In the case of polygamy, it is not ordered simply just like that, but it has certain laws and rules. (Aulawi, 1978: 33).

Zulkarnaini Abdullah illustrates the Islamic treatment of polygamy equal to the treatment of slavery (Abdullah, 2011, p. 174). The Koran does not prohibit slavery, although it advocates liberation of slaves. Islam encourages Muslims to realize that slavery is a dehumanizing act so that Muslim countries forbid slavery. Similarly, polygamy is initially restricted and given a certain condition with it. The development of polygamy in human history follows a society's view of women. Thus, the development of polygamy has ups and downs following the high degree of position and degree of women in the view of the community (Machali, 2005: 47). In Indonesian society, women are constructed with various myths. Women are placed in lower positions in social class, economy, politics and power. Cultural construction assumes that women are irrational or emotional so that women cannot appear to lead, resulting in an attitude that puts women in an unimportant position. In the community in Java, for example, there is still a presumption that women do not need to have high education, because they will eventually work in the kitchen as well (Fakih, 2003: 5). Even in its development, the type of "women's work" seems to be determined and firmly established in the minds of the people. Women may only perform domestic works. They are perceived as inferior to the type of work as what is called "men's work". They are categorized as unproductive, so they are not taken into account in the country's economic statistics (Fakih, 2003: 21).

In Banjar society, patriarchal culture is not obvious. Except leadership issues, especially regarding to religious understanding, women have a wide open opportunity to work. Banjar women basically have opportunities to get a higher education, many of whom become career women and have outside activities. Most school teachers in Banjar are women and the majority of 
traders in the floating market are women (Hendraswati, 2016: 97-115). It means that is no restriction for women to work outside. But when returning home, male leadership towards women will be visible. Wifes should serve and obey what the husband says, so girls should be respectful to their parents and brothers. It seems that leadership issues in the domestic sphere become irreversible in Banjar society. Many divorce cases occur because men feel that their rights as leaders in the household are not respected anymore. In terms of religious leadership, they can be seen differences in attitude in treating men and women. In Banjar there was never a tuan guru of the female sex. Title of tuan guru is only attached to a man who has a wide religious knowledge capacity, teaching many Islamic doctrines, leading some pengajian, and commiting to other things that in Islam should be done by a man, such as leading prayer and so on. No woman can claim to be a tuan guru even though she has also the capability of Islamic knowledge and spread the Islamic da'wah in the community. The title of honor that is often addressed to the Banjarese women who do dawah limited only to the term muballighah or daiyah, not ulama or tuan guru because both have become the privilege of men alone (Mudhi'ah, 2013).

Basically, the difference in attitudes that place the position of woman under the man is considered to be derived from a growing understanding of religious doctrine in Banjar society, that its religious principle is based on traditionalist attitudes and textual understanding. The Qur'an mentions that men are leaders for women in Surah al-Nisa' (v.34). This verse among the Banjarese is a jargon that shows men's hegemony against women, especially in the case of the family. They said that the male hierarchical power over women is an unchangeable decision of God. Moreover, this is supported by the text of the hadith about the woman's lack of reason and her religion (Narrated by Bukhari and Muslim). It is understood that women would never be equal to men in terms of reason and religion. No matter how high the religious knowledge of a woman, ho often she preaches and leads a pengajian, she will never get the title of ulama or tuan guru in Banjar society. Such culture eventually becomes established in the Banjar community.

In the case of polygamy by Banjarese, patriarchal culture will be seen in the elderly men who can force their daughters to marry the man of their choice, even if the man is married. Especially in the polygamous marriage of the tuan guru, some cases where the parents give their daughters to a tuan guru are found, the daughters cannot refuse for the sake of pleasing the parents. In this case, the position of the woman seems to have no bargaining value because in the religious sense of Banjarese, the daughter is the property of his father. It is 
also seen from the teachings in Islam that girls who are still girls can be forced by their parents to get maried, based on the concept of wali mujbir. ${ }^{10}$

While the basurung culture found in Banjar community, where the women offer themselves to marry, especially with the tuan guru, as discussed earlier, according to the writer, is a bold first step for Banjarese women to voice gender equality. If the fact that most women position themselves into polygamy as objects only, for women who do basurung, she has taken the first step to position herself as a subject in polygamous marriage. It means that from the beginning, she has taken the decision properly and well-prepared to accept all the consequences that will occur from her polygamous marriage. However, the decision of this basurung culture remains in the hands of men (the tuan guru). But still, this will certainly be different from women who have no choice but to accept only when he is polygamous. For feminists, this is called the standpoint difference, which will produce different results and acceptance as well.

The culture basurung for Banjar women actually can also be said as an attempt to break the tradition. First, the basurung initiative is a really bold act of breaking the established culture. In Banjar culture of marriage, there is a mindset that women can only wait for a man to propose instead of applying. Men choose and women are chosen, marriage will not happen if the man does not take the initiative. Secondly, in the case of the basurung culture to a tuan guru, the Banjar women show their readiness to consciously and rationally polygamy, not in the circumstances of being forced to accept the situation. The writer considers that being the polygamous spouse of a tuan guru actually becomes a strong attraction to do poligamy. It is not the same when the spouse is not tuan guru. It should be realized that the debate of pros-cons of polygamy is not only motivated by the theological understanding of the scripture (Al Qur'an), but also related to dialect with non-theological aspects such as cultural, social, and even economic elements in a community. With regards to the resistance of women in accepting polygamy or not, as categorized by Nurmila, Banjar women here are those who really like to participate in pengajian and those being discussed in this basurung culture mostly belong to the first category of those who accommodate polygamy well. This is certainly understood as such because of their intensity in accepting religious doctrines usually derived from ulama and tuan guru. The understanding of the source of Islamic Law is done textually and traditionally.

For the woman who offers herself, polygamy is seen as a way to justify her desire to marry a pious man, frequently without even thinking the feelings of his former wife. The case where the consciously basurung woman, without any

\footnotetext{
${ }^{10}$ The terminology is found in the laws of marriage in Islam.
} 
means of judgment, is basically impressed by her personal ego for having a good priest as a husband, that ends up hurting other women's feelings, especially the tuan guru's previous wife. Even sometimes the motivation of economic improvement can also be the reason of this 'basurung' culture. It is noted here that any woman or anyone who is 'basurung' will always has a strong special reason that motivates them to take the risk of a polygamous marriage, the marriage that becomes a scary scourge for most women. As for the previous wife, because the understanding of Islamic doctrine allows polygamy, she will be willing to accept her husband's polygamy even deep down in her heart, she feels hurt. Unfortunately the screams of women's hearts are often overlooked because religious doctrine has spoken. The former wife will not criticize the belief that a man is a leader in a household whose decision is not questionable, although a good man will certainly discuss it first with his wife. In spite of this, the former wife realized with all her heart the role of her husband as tuan guru of the community. In the end, the basurung culture itself is the result of the dialectic between the religious product and the social reality of Banjar society which is undeniably true, but it is true for a community only, those who do have emotional attachment with the tuan guru. The process occurs even in different ways in which each other is different. It is only because of a strong motivation that makes Banjar women dare to take this step.

\section{CONCLUSION}

The religious and gender issues in the practice of basurung and the polygamy of tuan guru in Banjar society is found to be very important. They are based on the understanding of the people about the teaching of Islam and the existing cultural understanding within the Bajarese toward the relation bertween tuan guru and theirs folloowers. The conclusion is supported by the fact that people have motivation and interests. First, the motivation of Banjar women doing basurung and asking to be married by tuan guru is mostly caused by the status of the tuan guru himself who has impressed the women. With the label of pious, religious, honorable, the level of the established economy a tuan guru can be regarded as the husband of dreams although the tuan guru has already got married. Secondly, such thinking actually grows because of the doctrines that have been implanted in the minds of the Banjarese since childhood that eventually it becomes an unquestionable habit. The acceptance of Banjarese, especially among women, toward polygamy practice is motivated by the understanding that they have been taught that polygamy is an Islamic doctrine. So in the minds of the people who are still very traditionalist, polygamous marriage is considered as a teaching that must be done. With the hope of a great religious reward, Banjarese will not refuse polygamy. The element of 
justice as the source of debate on the issue of polygamy seems to have never been questioned by the Banjarese, especially in tuan guru's polygamy. This is because of the belief that the knowledge of a tuan guru is wider and more qualified; a tuan guru is certainly capable of doing justice.

\section{BIBLIOGRAPHY}

Abdullah, Z., (2011). Meretas Jalan Islam: Telaah Masalah Filsafat, Pemikiran Politik, Islam dan Dinamika Masyarakat Muslim.. Langsa: STAIN Langsa.

AF, A. G., (2009). Sang Pelintas Batas: Biografi Djohan Effendi. Jakarta: ICRP.

Alhamdani, H., (1980). Risalah Nikah: Hukum Perkawinan Islam. Jakarta: Pustaka Amani.

Aulawi, A. S. d. A., (1978). Hukum Perkawinan Islam. Jakarta: Bulan Bintang.

Azhar, M., (1996). Fiqh Kontemporer dalam Pandangan Neomodernisme Islam. Yogyakarta: Pustaka Pelajar.

Chodjim, A., (2007). Benarkah Poligami Dibenarkan dalam Islam?. Paras: Bacaan Utama Wanita Islam, Februari.

Dahlan, A. A., (1997). Ensiklopedi Hukum Islam. Bandung: Ichtiar Baru Van Hoeve.

Daud, A., (1997). Islam dan Masyarakat Banjar: Deskripsi dan Analisa Kebudayaan Banjar. Jakarta: Grafindo Persada.

Fakih, M., (2003). Analisis Gender dan Transformasi Sosial. Yogyakarta: Pustaka Pelajar.

Ghazali, A. R., (2003). Fikh Munakahat. Jakarta: Prenada Media.

Hapip, A. D., (1977). Kamus Banjar-Indonesia. Jakarta: Departemen Pendidikan dan Kebudayaan.

Hendraswati, (2016). Etos Kerja Pedagang Pasar Terapung Lok Baintan di Sungai Martapura. Jurnal Pendidikan dan Kebudayaan, pp. 97-115.

Indonesia, D. P. N., (2008). Kamus Besar Bahasa Indonesia. Jakarta: Gramedia Pustaka Utama.

Machali, R., (2005). Wacana Poligami di Indonesia. Bandung: Mizan.

Makmur, A., (2012). Peranan Ulama dalam Membina Masyarakat Banjar di Kalimantan Selatan. MIQOT. Vol. XXXVI, pp. 174-191. 
Mudhi'ah, N., (2013). Dakwah dalam Pemberdayaan Perempuan (Studi Materi dan Kegiatan Dakwah yang Dilaksanakan Muballighah di Banjarmasin. Mu'adalah, pp. 37-49.

Mulia, S. M., (1999). Pandangan Islam terhadap Poligami. Jakarta: Solidaritas Perempuan-Lembaga Kajian dan Jender.

NorIpansyah, D., (2010). Bagampiran dan Pemakaian Jimat dalam Masyarakat Banjar. Banjarmasin: Antasari Press.

Nurmila, N., (2009). Women, Islam, and Everyday Life; Renegosiation Polygamy in Indonesia. New York: Routledge.

Roibin, (2007). Praktek Poligami di Kalangan Para Kiai (Studi Konstruksi Sosial PoligamiPara Kiai Pesantren di Jawa Timur), Malang: UIN Maulan Malik Ibrahim.

Saleh, M. I., (1991). Adat Istiadat dan Upacara Perkawinan Daerah Kalimantan Selatan.. Banjarmasin: Proyek Inventarisasi dan Pembinaan Nilainilai Budaya.

Setiati, E., (2007). Hitam Putih Poligami: Menelaah Perkawinan Poligami sebagai Sebuah Fenomena. Jakarta: Cisera Publishing.

Syaharuddin, (2009). Orang Banjar (Menjadi) Indonesia. Yogyakarta: Eja Publisher.

Syarqawi, Z. H., (2003). Fikih Seksual Suami-Istri. Solo: Media Insani Press.

Tradisional, D. S. d. N., (1985). Sejarah Sosial Daerah Kalimantan Selatan. Jakarta: Departemen Pendidikan dan Kebudayaan Indonesia.

WCC, L. R. A., (2001). Laporan Data Kasus 2001. Yogyakarta: Rifka Annisa.

Zaini, W., (1999). Peningkatan Peran Perempuan dalam Islam. Bandung: Mizan. 